\title{
Dialektika Hukum dan Moral dalam Perspektif Filsafat Hukum
}

\author{
Salman Luthan \\ Fakultas Hukum Universitas Islam Indonesia \\ Jl. Tamansiswa No. 158 Yogyakarta \\ sl_luthan@yahoo.com
}

\begin{abstract}
The research aims to study the dialectics between law and moral in the perspective of legal philosophy and examine the function of moral for law and law for moral. This study is a doctrinal-legal research that uses primary legal materials and a conceptual-juridical approach. The result indicates that the relationship between law and moral bears a reciprocal functional relation in law making and law enforcement. For law, moral functions as the source of ethics (values) in positive law making, source of rules in positive law, evaluative instrument for legal rule substances, and justification reference for settlement of legal cases that have unclear laws. Meanwhile, for moral, law functions as a medium that transforms individual moral rules into social legal rules with certain sanctions, strengthens moral values, principles, and rules, establishes new morality in the society, and enforce moral values, principles, and rules in social order.
\end{abstract}

Key words : Dialektika, bukum, moral

\begin{abstract}
Abstrak
Dalam penelitian ini masalah yang hendak diteliti, bagaimana dialektika antara hukum dan moral dalam perspektif filsafat hukum, dan bagaimana fungsi moral terhadap hukum dan sebaliknya fungsi hukum terhadap moral. Penelitian ini adalah penelitian hukum doktrinal, yang menggunakan bahan hukum primer, dengan pendekatan yuridis konsepsional. Penelitian ini menyimpulkan, adanya hubungan hukum dan moral melahirkan relasi fungsional yang resiprokal antara kedua entitas tersebut dalam pembentukan hukum dan penegakan hukum. Fungsi moralitas terhadap hukum meliputi: sumber etik (nilai) pembentukan hukum positif, sumber kaidah bagi hukum positif, instrumen evaluatif bagi substansi kaidah hukum, dan sumber rujukan justifikasi bagi penyelesaian kasus-kasus hukum yang tidak jelas aturan hukumnya. Adapun fungsi hukum terhadap moral terdiri dari fungsi mentransformasikan kaidah-kaidah moral yang bersifat individual menjadi kaidah hukum yang bersifat sosial dengan dukungan sanksi tertentu, memperkokoh nilai-nilai, prinsip-prinsip, dan kaidah-kaidah moral, membentuk moralitas baru dalam masyarakat, dan sarana untuk menegakkan nilai-nilai, prinsip-prinsip, dan kaidah-kaidah moral dalam tatanan kehidupan sosial.
\end{abstract}

Kata kunci : Dialektika, hukum, moral 


\section{Pendahuluan}

Diskursus pemikiran mengenai hubungan hukum dan moral dalam perspektif pemikiran hukum terpusat pada pertentangan pemikiran antara positivisme dan hukum kodrat (natural law). Pokok permasalahannya berkenaan dengan ada tidaknya hubungan di antara kedua kaidah tersebut yang berpengaruh terhadap keberadaan dan keabsahan aturan hukum sehingga mengikat warga masyarakat. Namun hubungan hukum dan moral jauh lebih luas dari sekedar pertentangan pemikiran antara positivisme dengan hukum kodrat. Hubungan hukum dan moral juga berkaitan dengan hubungan dialektis di antara kedua kaidah tersebut yang membentuk adanya relasi fungsional resiprokal antara hukum dan moral. Artinya, ada pengaruh timbal balik antara hukum dan moral dalam berbagai aspek kehidupan manusia, ada kontribusi moral terhadap hukum dan kontribusi hukum terhadap moral.

Dari perspektif historis dapat diketahui bahwa hukum dan moral pada awalnya bukanlah dua hal yang terpisah, melainkan dua aspek yang menyatu dalam hukum Tuhan (divine law). Hal ini bisa terlihat dari konsep hukum Yahudi, hukum Kanonik, dan hukum Islam. Menyatunya hukum dan moral sebagai instrumen untuk mengatur kehidupan masyarakat tercermin pula dalam kehidupan masyarakat atau komunitas tradisional (suku-suku terbelakang) yang belum banyak tersentuh oleh modernisasi.

Terpisahnya hukum dan moral dipengaruhi oleh sekulerisasi kehidupan manusia yang memisahkan antara kehidupan keduniaan yang menajadi urusan kenegaraan (politik) dan urusan keakhiratan yang menjadi domain moral dan agama. Meskipun pada awalnya sekulerisasi itu terjadi di dunia Barat (Kristen) dengan lahirnya "renaissance", namun gagasan sekulerisasi tersebut telah merambah hampir sebagian besar belahan dunia, termasuk dunia Islam. Di Indonesia ide sekulerisasi juga berkembang yang menampakkan dirinya dalam diskursus hubungan negara dan agama dan derivasi dari pola hubungan tersebut.

Penelitian ini bermaksud mendeskripsikan dialektika hukum dan moral yang akan mengupas hubungan dialektis antara hukum dan moral yang inti pembahasannya terfokus pada pola hubungan hukum dan moral, fungsi moral terhadap hukum, dan fungsi hukum terhadap moral. 


\section{Rumusan Masalah}

Berdasarkan uraian di latar belakang masalah di atas, maka penelitian ini difokuskan pada permasalahan: pertama, bagaimana dialektika antara hukum dan moral dalam perspektif filsafat hukum? Kedua, bagaimana fungsi moral terhadap hukum dan sebaliknya fungsi hukum terhadap moral?

\section{Tujuan Penelitian}

Adapun tujuan dari penelitian ini adalah untuk mendeskripsikan dan menganalisis: pertama, dialektika antara hukum dan moral dalam perspektif filsafat hukum. Kedua, fungsi moral terhadap hukum dan sebaliknya fungsi hukum terhadap moral.

\section{Metode Penelitian}

Penelitian ini merupakan penelitian hukum doktrinal yang menggunakan bahan hukum primer. Teknik pengumpulan data menggunakan studi pustaka. Metode analisis yang digunakan adalah deskriptif kualitatif.

\section{Hasil Penelitian dan Pembahasan}

Para yuris telah bergulat mencari esensi hukum sejak zaman Yunani hingga hari ini, dan sudah cukup banyak pengertian atau definisi hukum yang mereka kemukakan. Namun tetap saja tidak ada definisi yang memuaskan dan diterima semua kalangan hukum. Esensi hukum yang dikemukakan para yuris ada bermacam-macam ditinjau dari sudut pandang yang beraneka ragam. Adakalanya pengertian yang satu bertentangan dengan pengertian yang lain.

Menurut Selznick, hukum berkaitan dengan usaha untuk mewujudkan nilainilai tertentu. ${ }^{1}$ Oliver Wendel Holmes mengemukakan bahwa "the life of law has not been logic: it has experience" ${ }^{2}$ (esensi kehidupan hukum bukan sesuatu yang menjadi logis, tapi sesuatu yang menjadi pengalaman). Menurut Sudikno Mertokusumo, kaidah hukum merupakan ketentuan atau pedoman tentang apa

\footnotetext{
${ }^{1}$ M. Samsudin mengutip pendapat Satjipto Rahardjo dalam Budaya Hukum Hakim, Edisi Pertama, Kharisma Putra Utama, Jakarta, 2012, hlm. 45.

${ }^{2}$ Satjipto Rahardjo, Penegakan Hukum Progresif, PT. Kompas Gramedia Nusantara, Jakarta, 2010, hlm. 7.
} 
yang seyogianya atau seharusnya dilakukan. ${ }^{3}$ Dilihat dari lingkup pengaturannya, hukum adalah keseluruhan peraturan-peraturan dimana tiap-tiap orang yang bermasyarakat wajib mentaatinya. ${ }^{4}$

Namun esensi hukum yang dimaksud dalam kajian ini adalah konsep hukum sebagai himpunan nilai-nilai, asas-asas dan norma-norma perilaku yang berfungsi untuk mengatur tingkah laku manusia dalam kehidupan masyarakat yang ditegakkan dengan sanksi yang dapat dipaksakan kepada para pelanggarnya guna membangun ketertiban dan ketenteraman (keadilan) dalam kehidupan masyarakat.

Sedangkan esensi moral yang dimaksud dalam tulisan ini adalah norma-norma moral, yaitu norma yang menentukan apakah perilaku kita baik atau buruk dari sudut etis. Karena itu norma moral adalah norma tertinggi, yang tidak bisa ditaklukkan pada norma lain. ${ }^{5}$ Norma Moral tersebut adalah kewajiban atas dasar kesusilaan dan kesopanan. ${ }^{6}$

Ukuran moralitas suatu perbuatan, baik atau buruk, ditentukan oleh dua faktor, yakni ukuran subyektif dan ukuran umum atau obyektif berlandaskan kepada norma-norma tertentu. Hati nurani seseorang secara subyektif memberitahukan kepada dirinya mana yang baik dan mana yang buruk. Norma-norma secara umum memberitahukan kepada semua orang tentang perbuatan yang baik dan buruk.

Kategoris imperatif yang berasal dari Kant yang mungkin merupakan tolok ukur yang paling terkenal dalam semua fisafat moral yang merebut perhatian publik. Kategori imperatif itu adalah "perbuatan hanya bersesuaian dengan maxim (moral) dengan jalan mana kamu pada waktu yang sama mendapatkan bahwa perbuatan itu akan menjadi hukum yang universal". ${ }^{7}$ Artinya, suatu perbuatan sejalan dengan moral bila perbuatan itu mengandung nilai universal.

Secara umum masyarakat kita mengharapkan orang untuk melakukan sesuatu yang benar, termasuk memenuhi tugas-tugas moral mereka, yaitu kewajibankewajiban yang bersesuaian dengan perasaan dasar manusia mengenai benar salah (sense of right and wrong) di mana orang harus mengikutinya. ${ }^{8}$ Perasaan dasar manusia mengenai benar salah ini ada yang mengkualifikasikannya sebagai hati nurani.

${ }^{3}$ Sudikno Mertokusumo, Mengenal Hukum, Cetakan ke 1, Penerbit Universitas Atmajaya,Yogyakarta, 2010, hlm. 7.

${ }^{4}$ Marwan dan Jimmy P, Kamus Hukum, Cetakan Pertama, Reality Publisher, Surabaya, 2009, hlm. 258.

${ }^{5}$ K. Bertens, Etika, Cetakan Kesebelas, Penerbit Gramedia Pustaka Utama, Jakarta, 2011, hlm. 159.

${ }^{6}$ Martin Basiang, Law Dictionary, First Edition, Red \& White Publishing, Jakarta, hlm. 294.

${ }^{7}$ Sam Harris, The Moral Landscape How Science Can Determine Human values, Transworld Publisher, London, 2010, hlm. 81-82.

${ }^{8}$ Richard G. Singer dan John Q. La Fond, Criminal Law, $4^{\text {th }}$ ed, Aspen Publisher, New York, 2007, hlm. 41. 
Hati nurani sebagai tolok ukur moralitas teridentifikasi melalui respon hati nurani terhadap tindakan yang dilakukan. Perbuatan baik yang dilakukan seseorang bukan hanya akan mendapatkan persetujuan hati nurani, tapi juga mendatangkan ketenteraman batin bagi orang bersangkutan. Namun sebaliknya, perbuatan buruk yang dilakukan seseorang akan mengundang protes nurani, menimbulkan kegelisahan batin, dan rasa penyesalan diri.

Kelemahan hati nurani sebagai ukuran moralitas terletak pada relativitas kebenaran hati nurani karena ia bersifat subyektif, tergantung kepada kesadaran masing-masing orang. Hati nurani manusia ibarat sebuah cermin yang berfungsi untuk berkaca. Bila cermin itu bersih, maka seseorang dapat berkaca secara jelas mengenai keberadaan dirinya, namun bila cermin itu penuh dengan noda atau kotor, maka orang tidak bisa berkaca dengan baik. Hati nurani yang bersih dapat membedakan perbuatan baik dan buruk secara nyata, namun hati nurani yang penuh dengan noda tidak akan dapat memilah antara perbuatan baik dengan perbuatan buruk.

Ukuran moralitas obyektif yang bersadarkan kepada norma-norma meliputi norma agama, ideologi, kebiasaan atau tradisi, dan hukum. Agama mengajarkan kepada manusia mana perbuatan baik yang harus dilakukan, dan mana perbuatan buruk yang harus ditinggalkan. Penentuan baik buruknya perbuatan dalam agama merupakan otoritas Tuhan. Suatu perbuatan dikualifikasikan baik karena Tuhan menetapkannya demikian, begitu pula sebaliknya. Dengan kata lain,penentuan baik buruk dalam perspektif agama berdasarkan kepada doktrin agama yang merupakan firman Tuhan.

Moralitas dalam perspektif agama terdiri dari doktrin moral menurut Islam, Kristen, Katolik, Yahudi, dan Budha, dan sebagainya. Tolok ukur moralitas dalam perspektif agama mempunyai banyak persamaan, tapi juga memiliki perbedaan. Misalnya perbedaan doktrin Islam dan Kristen mengenai kehalalan babi dan keabsahan poligami. Moralitas dalam perspektif ideologi misalnya moralitas menurut ideologi utilitarianisme, sosialisme, dan kapitalisme.

Ukuran moralitas menurut kebiasaan berlandaskan kepada tradisi yang hidup dalam masyarakat. Tradisi menunjukkan kepada kita melalui pergaulan hidup masyarakat, mana perbuatan susila dan mana perbuatan yang asusila, mana perbuatan yang sejalan dengan pandangan masyarakat, dan mana perbuatan yang antisosial atau perilaku menyimpang (deviant behavior). Otoritas menentukan baik buruk perbuatan manusia menurut tradisi adalah otoritas masyarakat. Suatu 
perbuatan dikualifikasikan baik atau buruk karena masyarakat menhendakinya demikian.

\section{Pola Hubungan Hukum dan Moral}

Ada empat macam pola hubungan hukum dan moral. Pertama, hukum merupakan bagian dari satu sistem ajaran moral. Ajaran moral adalah prinsip-prinsip dan kaidah-kaidah moral yang terdapat dalam berbagai agama, ideologi, filsafat dan tradisi masyarakat. Pola hubungan hukum dan moral seperti ini terdapat dalam moral agama di mana hukum (agama) merupakan bagian dari ajaran moral agama. Aspek lain ajaran agama meliputi teologi, peribadatan, akhlak, politik dan ekonomi. Dengan demikian, hukum-hukum yang bersumber pada agama merupakan bagian dari sistem ajaran moral agama.

Hukum Islam (syariah) merupakan bagian dari ajaran moral agama Islam, dan hukum Yahudi (Jewish law) merupakan bagian dari moral agama Yahudi. Hukum Islam terdiri dari berbagai subsistem hukum, yaitu hukum pidana (jinayah), hukum kenegaraan (assiyasah), hukum keperdataan (muamalah), hukum perkawinan (munakahah) dan hukum waris (faraid). Hukum Yahudi bersumber kepada Taurat dan Zabur yang terkenal dengan sebutan Perjanjian Lama (Old Testament). Perjanjian Lama dikembangkan oleh rabbi-rabbi Yahudi menjadi pemikiran-pemikiran hukum aktual dan kontekstual yang disebut dengan hukum Talmud. Hukum Talmud itu dikompilasikan dalam dua kitab, Babylonia Talmud dan Jerussalem Talmud. Hukum Kristen yang bersumber pada Injil dikembangkan oleh para pemukanya pada abad pertengahan dalam hukum Kanonik (canonic law).

Pola hubungan hukum dan moral yang menempatkan hukum sebagai bagian dari ajaran moral agama tidak banyak dikaji dan diperbincangkan karena terdesak oleh gagasan sekulerisasi agama dan positivisme moral yang berlandaskan kepada tradisi. Akibatnya, gagasan-gagasan hukum agama kurang berkembang dan berpengaruh terhadap pemikiran-pemikiran hukum positif dan kebijakan pembentukan hukum. Di samping itu, faktor lain yang menyebabkan kurang berkembangnya hukum-hukum agama adalah sikap para ahli agama yang terlalu normatif dalam memahami teks-teks hukum agama dan persoalan-persoalan hukum kontekstual.

Pola hubungan hukum dan moral yang menempatkan hukum sebagai bagian dari ajaran moral dapat pula diterapkan terhadap sistem hukum yang bersumber pada 
ideologi. Sistem hukum sosialis merupakan subsistem dari ideologi komunis atau sosialis yang pada masa lalu berlaku di negara-negara yang menganut ideologi tersebut, terutama di negara-negara bekas Uni Soviet. Namun kini keberadaan sistem hukum sosialis cenderung semakin redup bersamaan dengan bangkrutnya ideologi komunisme.

Kedua, hukum merupakan derivasi dari prinsip-prinsip atau kaidah-kaidah moral umum. Artinya, hukum merupakan penjabaran dari prinsip-prinsip moral umum yang berlaku secara universal dan mengatasi berbagai kebudayaan. Prinsipprinsip moral umum, menurut penganut hukum kodrat, terdapat dalam moralitas kodrati yang bersumber kepada prinsip-prinsip kodrat alam (sunnatullah) yang bersifat tetap dan abadi. Prinsip-prinsip moralitas umum itu disebut pula dengan hukum kodrat yang mempunyai kedudukan lebih tinggi dari hukum positif. Dengan demikian, hukum positif merupakan derivasi dari hukum kodrat. Oleh karena itu, hukum positif tidak boleh bertentangan dengan hukum kodrat.

Dalam pandangan hukum kodrat, hukum identik dengan keadilan (ius quia iustum) Keabsahan suatu aturan hukum tergantung pada kesesuaian aturan hukum tersebut dengan prinsip-prinsip moralitas, khususnya prinsip keadilan. Suatu aturan, termasuk undang-undang, tidak memenuhi syarat untuk dikualifikasikan sebagai hukum jika aturan tersebut bertentangan dengan prinsip-prinsip keadilan.

Ketiga, ada persinggungan (titik singgung) antara kaidah hukum dan kaidah moral. Artinya, ada bagian dari tingkah laku manusia yang sama-sama diatur oleh kedua kaidah itu. M. Rasjidi menggambarkan persinggungan hukum dan moral dalam dua lingkaran (circle), di mana ada bagian kedua lingkaran tersebut yang saling berhimpitan. Dalam bagian yang berhimpitan itu hukum dan moral bersamaan, sedang dalam bagian lain, tidak ada persamaan. Sesuatu yang legal belum tentu yang moral dan yang moral belum tentu yang legal. Sedangkan J.J.H. Bruggink menggambarkan persinggungan tersebut dalam tiga kotak segi empat yang saling bersambungan dimana kota di posisi tengah merupakan kotak yang berisi muatan hukum dan moral.

Hukum mempunyai hubungan yang sangat erat dengan moral karena kedua kaidah tersebut sama-sama mengatur tingkah laku manusia dan sama-sama bertujuan untuk menciptakan kebaikan bagi hidup manusia. Sering terjadi perbuatan yang dilarang oleh moral dilarang pula oleh hukum, namun sebaliknya kadangkala perbuatan yang dilarang oleh moral tidak dilarang oleh hukum dan apa yang dilarang oleh hukum tidak dilarang oleh moral. 
Hukum di semua negara modern dalam berbagai seginya memperlihatkan adanya hubungan (pengaruh) dengan moralitas sosial yang diterima maupun citacita moral yang lebih luas. Berbagai pengaruh ini masuk ke dalam hukum entah dengan cepat dan resmi melalui legislasi, atau secara diam-diam dan setahap demi setahap melalui proses yudisial. Dalam sebagian sistem, seperti di Amerika Serikat, kriteria terakhir (ultimate) validitas hukum meliputi secara eksplisit prinsip-prinsip keadilan atau nilai-nilai moral substantif; dalam sistem lainnya, seperti di Inggris, di mana tidak ada batasan-batasan formal atas kompetensi badan legislatif tertinggi, legislasinya pun tidak kalah ketatnya dalam berpegang pada keadilan atau moralitas. ${ }^{9}$

Tidak seorang pun 'penganut positivisme' yang bisa menyangkal bahwa halhal ini adalah fakta, atau bahwa stabilitas sistem-sistem hukum untuk sebagian bergantung pada tipe-tipe kesesuaian dengan moral seperti itu. Jika yang dimaksud dengan hubungan perlu antara hukum dan moral adalah seperti ini, tentu saja keberadaannya bisa diterima. ${ }^{10}$

Klaim bahwa ada hubungan perlu antara hukum dan moralitas terkadang berujung pada pendirian bahwa sebuah sistem hukum yang baik harus sejalan pada segi tertentu dengan, seperti telah tersebut dalam paragraf terakhir, ketentuanketentuan keadilan dan moralitas. ${ }^{11}$

Keempat, tidak ada hubungan antara hukum dengan moral, karena kedua bidang itu bukan hanya dua hal yang terpisah, tapi juga dua aspek yang berbeda. Berbedanya atau terpisahnya hukum dan moral dapat digambarkan dalam skema dua lingkaran yang tidak mempunyai titik singgung, lingkaran yang satu adalah moral dan lingkaran yang lainnya ialah hukum. Pola hubungan hukum dan moral yang keempat ini mewakili pandangan positivisme. John Austin mengungkapkan bahwa keberadaan hukum berbeda dari kebaikan atau keburukan hukum.

Perbedaan kaidah hukum dan kaidah moral, menurut van Apeldorn, ${ }^{12}$ ada lima macam. Kaidah hukum dan kaidah moral memiliki perbedaan tujuan. Hukum bertujuan untuk menciptakan ketertiban dan ketenteraman masyarakat, sedangkan moral mempunyai tujuan untuk menyempurnakan kehidupan pribadi seseorang. Tercapainya tujuan kaidah moral secara tidak langsung akan membawa pengaruh terhadap upaya pencapaian tujuan kaidah hukum karena pribadi yang baik

\footnotetext{
${ }^{9}$ H.L.A. Hart, Konsep Hukum, The Concept of Law, Cetakan Pertama, Penerbit Nusa Media, Bandung, 2009, hlm. 315. ${ }^{10}$ Ibid., hlm. 315-316.

${ }^{11}$ Ibid., hlm. 317.

${ }^{12}$ Van Apeldorn, Pengantar Imu Hukum, PT.Pradnya Paramita, Jakarta, 1982, hlm. 35-40.
} 
cenderung menaati aturan-atuaran hukum yang merupakan pedoman bagi setiap manusia dalam kehidupan masyarakat.

Selain perbedaan tujuan, hukum dan moral berbeda pula dalam aspek isi aturan. Kaidah hukum mengatur perbuatan-perbuatan lahir manusia, artinya hukum memusatkan fokus pengaturannya kepada sikap dan prilaku lahiriah, bukan kepada sikap batin manusia. Dalam hal ini hukum menganut asas "cogitationis poenam nemo patitur", yang berarti "tak sesorang pun dapat dihukum untuk apa yang dipikirkannya". Sebaliknya, kaidah moral mengatur sikap batin manusia yang menjadi motif perbuatan lahiriah.

Selanjutnya perbedaan mengenai asal usul kaidah. Menurut Immanuel Kant, kaidah hukum bersifat heteronom, sedangkan moral bersifat otonom. Sifat heteronom kaidah hukum mengandung arti bahwa kekuasaan dari luarlah yang memaksakan kehendaknya kepada manusia, yaitu kekuasaan masyarakat atau negara. Orang tunduk kepada hukum karena ada kekuasaan yang memaksa mereka untuk taat tanpa syarat.

Sedangkan sifat otonom kaidah moral mengandung arti bahwa perintah moral berdasarkan kehendak seseorang terhadap dirinya sendiri. Tiap-tiap orang harus menentukan menurut suara hatinya, apakah yang dituntut moral terhadap dirinya sendiri. Kaidah moral ditaati oleh manusia karena dorongan kehendak (kesadaran) diri sendiri.

Hukum dan moral memiliki perbedaan pula dalam instrumen penegakannya. Moral berakar dalam suara hati manusia, dari kekuatan batin yang terdapat dalam diri manusia. Ketaatan kepada kaidah moral bersifat sukarela. Satu-satunya kekuasaan yang menyokong moral adalah kekuasaan suara hati manusia. Ketaatan kepada kaidah hukum tidak hanya ditopang oleh kekuatan batin dari suara hati manusia, melainkan terutama dipaksakan oleh alat-alat kekuasaan lahir. Dengan demikian, hukum mempunyai dua kekuatan mengikat, yakni kekuatan mengikat lahir dan kekuatan mengikat batin.

Akhirnya, hukum dan moral memiliki perbedaan dalam daya kerjanya. Kaidah hukum bukan hanya membebankan kewajiban kepada manusia (normatif), tapi juga memberikan kekuasaan (atributif). Sedangkan kaidah moral hanya membebankan kewajiban saja kepada manusia, artinya semata-mata bersifat normatif.

Di samping perbedaan yang dikemukakan Apeldorn, kaidah hukum dan kaidah moral juga mempunyai perbedaan dalam lingkup pengaturannya. Kaidah 
hukum adalah aturan untuk mengatur kehidupan bermasyarakat, sedangkan moral merupakan kaidah untuk mengatur kehidupan pribadi manusia. Perbedaan lainnya berkenaan dengan sifat universalitas yang menjadi ciri kaidah moral, dan sifat nasionalitas yang menjadi karakteristik hukum.

Menurut Immanuel Kant, kaidah hukum bersifat heteronom, sedangkan kaidah moral bersifat otonom. Sifat heteronom kaidah hukum mengandung arti bahwa kekuasaan dari luarlah yang memaksakan kehendaknya kepada manusia, yaitu kekuasaan masyarakat atau negara. Orang tunduk kepada hukum karena ada kekuasaan yang memaksa mereka untuk taat tanpa syarat. Sedangkan sifat otonom kaidah moral mengandung arti bahwa perintah moral berdasarkan kehendak seseorang terhadap dirinya sendiri. Tiap-tiap orang harus menentukan menurut suara hatinya, apakah yang dituntut moral terhadap dirinya sendiri. Kaidah moral ditaati oleh manusia karena dorongan kehendak (kesadaran) diri sendiri.

Hukum dan moral memiliki perbedaan pula dalam instrumen penegakannya. Moral berakar dalam suara hati manusia, dari kekuatan batin yang terdapat dalam diri manusia. Ketaatan kepada kaidah moral bersifat sukarela. Satu-satunya kekuasaan yang menyokong moral adalah kekuasaan suara hati manusia. Sebaliknya, ketaatan kepada kaidah hukum tidak hanya ditopang oleh kekuatan batin dari suara hati manusia, melainkan terutama dipaksakan oleh alat-alat kekuasaan lahir yang berupa institusi dan aparatur penegak hukum. Dengan demikian, hukum mempunyai dua kekuatan mengikat, yakni kekuatan mengikat lahir dan kekuatan mengikat batin.

Dalam zaman sekarang ini terutama sesudah perang dunia kedua, bertambahlah kesadaran bahwa hukum harus dikaitkan dengan moral (keadilan) supaya dapat dipandang sebagai hukum. Atau dengan kata lain, orang makin yakin bahwa hukum positif harus menurut norma-norma yang tertentu, yakni prinsip-prinsip keadilan. Bila tata hukum hukum yang tidak memenuhi syarat ini, tetap diakui sebagai hukum, maka dengan ini hukum sebenarnya tidak dapat dibedakan lagi dari kekuasaan. ${ }^{13}$

Dalam konteks adanya hubungan antara hukum dengan moral terdapat relasi fungsional yang bersifat resiprokal antara kedua kaidah tersebut. Artinya, kedua kaidah sosial itu mempunyai hubungan fungsional timbal balik: moral mempunyai fungsi tertentu terhadap hukum, dan sebaliknya hukum juga mempunyai fungsi

\footnotetext{
${ }^{13}$ Sukarno Aburaera dkk, Filsafat Hukum, Cetakan Pertama, Pustaka Refleksi, Makassar, 2010, hlm. 33.
} 
tetentu terhadap moral. Relasi fungsional antara hukum dan moral terutama terlihat dalam pembentukan kaidah hukum dan dalam penegakan hukum dan moral.

\section{Fungsi Moral terhadap Hukum}

Moral mempunyai lima fungsi terhadap hukum pertama, moral berfungsi sebagai landasan etik bagi pembentukan kaidah hukum. Sebagai landasan etik, nilainilai moral menjadi dasar kebijakan untuk membentuk kaidah-kaidah hukum baru dan untuk memperbarui kaidah-kaidah hukum yang berlaku karena sudah tidak sesuai lagi dengan kebutuhan hukum dan tingkat perekembangan masyarakat. Nilainilai moral, khususnya nilai-nilai keadilan bagi semua orang dan nilai-nilai kebajikan dalam pergaulan hidup manusia harus menjiwai dan mengarahkan pembentukan kaidah-kaidah hukum (undang-undang). Penetapan hak dan kewajiban dalam suatu hubungan hukum dan penetapan suatu perbuatan sebagai perintah atau larangan harus megacu kepada nilai-nilai keadilan bagi semua orang dan nilai-nilai kebajikan dalam pergaulan hidup manusia.

Kedua, moral merupakan sumber hukum. Artinya, kaidah-kaidah moral dapat menjadi sumber bagi pembentukan kaidah-kaidah hukum. Implementasi fungsi moral sebagai sumber hukum dilakukan melalui penetapan perbuatan-perbuatan yang tidak baik secara moral (imral) menjadi perbuatan yang melawan hokum (illegal) atau perbuatan kriminal (tindak pidana). Di samping itu, perbuatan-perbuatan yang tidak sah secara moral tidak boleh ditetapkan sebagai perbuatan yang illegal atau kriminal. Dengan demikian ada signifikansi antara moralitas dengan legalitas dan immoralitas dengan illegalitas atau kriminalitas.

Perbuatan yang dikualifikasikan sebagai perbuatan immoral seperti mengingkari janji, merugikan kepentingan orang lain, menyembunyikan cacat barang yang mau dijual dapat dijadikan sebagai perbuatan melawan hukum dalam bidang hukum perdata. Di samping itu, perbuatan mencuri, membunuh, berzina yang termasuk kualifikasi perbuatan immoral dikualifikasikan sebagai kejahatan (tindak pidana) yang diancam dengan sanksi pidana tertentu.

Ketiga, moral merupakan sarana untuk menguji (evaluasi) keberadaan kaidah hukum. Apakah suatu kaidah atau aturan sudah memenuhi kualifikasi moralitas untuk disebut sebagai hukum atau belum? Dan apakah kaidah hukum itu telah memenuhi kualifikasi hukum yang adil atau hukum yang baik dalam perpektif moral? 
Menurut Fuller, terdapat delapan moral hukum internal, yaitu: delapan nilai yang harus diwujudkan oleh hukum. Kedelapan nilai tersebut dinamakan delapan prinsip legalitas, yaitu: (i) harus ada peraturan terlebih dahulu, berarti bahwa tidak ada tempat bagi keputusan-keputusan secara ad-hoc, atau tindakan-tindakan yang bersifat arbitrer; (ii) peraturan itu harus diumumkan secara layak; (iii) peraturanperaturan itu tidak boleh berlaku surut; (iv) perumusan peraturan itu harus jelas dan terperinci, artinya harus dapat dimengerti oleh rakyat; (v) hukum tidak boleh dijalankannya hal-hal yang tidak mungkin; (vi) di antara sesama peraturan tidak boleh terdapat pertentangan satu sama lain; (vii) peraturan harus tetap, tidak boleh sering diubah-ubah; (viii) harus ada kesesuaian antara tindakan-tindakan para pejabat hukum dan peraturan yang telah dibuat. ${ }^{14}$

Keempat, moral menjadi rujukan justifikasi untuk menyelesaikan kasus-kasus hukum yang tidak ada dasar hukumnya atau tidak jelas dasar hukumnya. Sudah menjadi hal yang lazim bagi hakim untuk mencari pembenaran terhadap putusan- berdasarkan pertimbangan-pertimbangan moral. Dalam konsep hukum perdata, perbuatan melawan hukum bukan hanya berarti perbuatan yang melanggar undang-undang, tapi juga perbuatan yang bertentangan dengan kepatutan dan kesusilaan. Dalam konteks ini, melanggar aturan hukum sama dengan melanggar kaidah-kaidah moral.

Menkonstruksikan pelanggaran moral sebagai pelanggaran hukum dalam bidang hukum perdata dapat menjadi instrumen untuk menyelesaikan sengketa privat antara seseorang dengan orang lain guna mencari perdamaian (keadilan) di antara mereka. Perdamaian di antara pihak yang bersengketa merupakan tujuan akhir yang hendak dicapai oleh pihak yang bersengketa dalam lapangan hukum perdata. Namun menkonstruksikan pelanggaran moral sebagai pelanggaran hukum dalam bidang hukum pidana dapat merusak sistem hukum pidana yang berlandaskan kepada asas legalitas (legality principle).

Dalam hukum perancis, diatur dalam Pasal 6 Civil Code Perancis, sebuah kausa akan tidak diperbolehkan secara hukum apabila ia dilarang oleh hukum, atau bertentangan dengan moral (bonnes moeurs) atau ketertiban umum (ordere publik). Di dalam hukum Jerman, konsep tunggal dari moral yangh baik telah digunakan, yang mengikutsertakan ketentuan umum dan juga dapat menganulir semua transaksi yang bertentangan dengan aturan yang sangat penting ini. ${ }^{15}$

\footnotetext{
${ }^{14}$ M. Samsudin, Op. Cit., 2012, hlm. 45.

${ }^{15}$ Peter de Cruz, Perbandingan Sistem Hukum, Penerbit Nusa Media, Jakarta, 2010, hlm. 372.
} 
Dengan mengkonstruksikan pelanggaran moral sebagai pelanggaran hukum pidana berarti memberi cek kosong kepada penguasa untuk menggunakan kekuasaannya dalam menetapkan suatu perbuatan sebagai tindak pidana yang diancam dengan sanksi pidana tertentu atau dalam menafsirkan ketetuan hukum pidana. Mengkonsruksikan pelanggaran moral sebagai pelanggaran hukum pidana dapat mendorong penguasa melakukan penyalahgunaan kekuasaan (abuse of power) atau menggunakan kekuasaan secara sewenang-wenang.yang dapat merugikan hak asasi dan hak-hak hukum warganegara, apalagi sengketa dalam hukum pidana bukan sengketa antara seseorang dengan orang lain, tapi sengketa anatar negara dengan warganegara yang tujuan akhirnya menghukum orang bersalah dan membebaskan orang yang tidak bersalah,

Kelima, kesadaran moral masyarakat dapat menunjang kepatuhan masyarakat kepada aturan-aturan hukum, khususnya aturan-aturan hukum yang sejalan dengan kaidah-kaidah moral. Ketaatan seseorang terhadap kaidah-kaidah moral dilandasi oleh kesadaran diri bahwa kaidah-kaidah moral tersebut merupakan aturan yang baik bagi kehidupan pribadinya. Kesadaran diri untuk menaati kaidah-kaidah moral yang dilakukan oleh orang banyak akan menjadi kesadaran kolektif anggota masyarakat mengenai pola hidup baik dalam kehidupan bersama.

Dalam konteks moral, orang secara sukarela mewajibkan dirinya untuk menaati kaidah-kaidah moral karena kaidah-kaidah moral tersebut sesuai dengan hati nuraninya dan cara hidup baik yang dipersepsikannya. Seseorang mewajibkan dirinya untuk melaksanakan perintah-perintah moral, misalnya perintah untuk berbuat baik kepada sesama manusia, perintah untuk menepati janji, dan perintah untuk bersikap jujur, karena perintah moral tersebut sesuai dengan pola hidup baik yang diyakininya. Begitu pula bila seseorang mewajibkan dirinya untuk tidak mengikuti larangan-larangan moral, seperti mencuri, memperkosa, berzina, dan menipu, karena larangan-larangan tersebut bertentangan dengan cara hidup baik.

Fenomena kepatuhan masyarakat kepada aturan-aturan hukum tidak bisa langsung dimaknai sebagai ketakutan masyarakat kepada sanksi hukum yang diancamkan terhadap norma hukum tertentu. Kepatuhan masyarakat kepada aturanaturan hukum mungkin pertama-tama didorong oleh kepatuhan pribadi-pribadi anggota masyarakat kepada kaidah-kaidah moral yang sejalan dengan kaidah-kaidah hukum. Namun demikian, kepatuhan masyarakat kepada aturan hukum dapat juga hanya didorong oleh adanya ketakutan terhadap sanksi hukum yang akan dijatuhkan 
terhadap para pelanggar hukum. Kepatuhan masyarakat terhadap aturan hukum dapat didorong oleh kepatuhan pribadi-pribadi anggota masyarakat kepada kaidahkaidah moral, dan sekaligus ketakutan terhadap sanksi hukum yang akan diancamkan terhadap aturan hukum tertentu.

Kesadaran moral bukan hanya dapat mendorong kepatuhan masyarakat terhadap aturan hukum, tapi juga dapat menjadi pemicu pembangkangan terhadap sistem hukum, norma hukum tertentu, atau praktek penegakan hukum (pembangkangan sipil). Kesadaran moral dapat memicu terjadinya pembangkangan sipil bila sistem hukum, aturan hukum, dan praktek penegakan berjalan secara tidak adil, penuh diskriminasi terhadap warga negara. Revolusi sosial yang terjadi di berbagai negara dipicu oleh kesadaran moral masyarakat untuk melawan penindasan yang diakukan oleh rezim yang berkuasa.

\section{Fungsi Hukum Terhadap Moral}

Fungsi hukum terhadap moral ada empat macam. Pertama, mentransformasikan kaidah moral yang bersifat individul menjadi kaidah hukum yang bersifat kolektif untuk mengatur masyarakat. Dalam substansi transformasi kaidah moral menjadi kaidah hukum mencakup pula transformasi sanksi moral yang bersifat personal dan batiniah menjadi sanksi hukum yang bersifat kolektif (negara atau masyarakat) dan lahiriah.

Transformasi kaidah moral menjadi kaidah hukum dlakukan melalui proses legislasi. Perbuatan-perbuatan yang bersifat immoral ditransformasikan menjadi menjadi perbuatan melawan hukum (illegal) atau perbuatan kriminal (tindak pidana). Kaidah moral yang ditransformasikan menjadi kaidah hukum perdata misalnya perbuatan mengingkari janji, pelanggaran prinsip iktikad baik, perbuatan merugikan kepentingan orang lain. Adapun beberapa contoh kaidah moral yang ditransformasikan menjadi kaidah hukum pidana meliputi pembunuhan, perkosaan, pencurian, dan perzinahan.

Norma-norma sopan santun menjadi norma hukum, padahal sopan santun itu bagian dari moral atau etika yang kemudian menjadi norma hukum karena normanorma itu berlaku secara moral, kemudian dijadikan itu hukum juga, sehingga norma mopral akan lebih efektif bagi hidup bermasyarakat, dengan demikian antara hukum dan moral tidak dapat dipisahkan. ${ }^{16}$

${ }^{16}$ M. Agus Santoso, Hukum, Moral \& Keadilan, Edisi Perdana, Penerbit Kencana Prenada Media Group, Jakarta, 2012, hlm. 90. 
Ditransformasikannya kaidah moral menjadi kaidah hukum berarti kedudukan kaidah moral sebagai salah satu norma dalam pergaulan hidup masyarakat menjadi semakin kuat karena kaidah moral bukan lagi hanya kaidah intern personal, tapi juga sudah menjadi kaidah antar personal (sosial) yang ditegakkan melalui institusi hukum formal negara (kepolisian, kejaksaan dan pengadilan).

Kedua, memperkuat kedudukan nilai-nilai, prinsip-prinsip, dan kaidah-kaidah moral dalam kehidupan personal dan sosial, khususnya nilai-nilai, prinsip-prinsip, dan kaidah-kaidah moral yang ditransformasikan menjadi kaifah hukum. Upaya memperkuat nilai-nilai, prinsip-prinsip, dan kaidah-kaidah moral dilakukan melalui proses penegakan hukum yang berjalan secara efektif dan efisien. Penegakan nilai-nilai, prinsip-prinsip, dan kaidah hukum yang bersumber daeri kaidah-kaidah moral yang berjalan efektif dan efisen bukan hanya berimplikasi kepada kepatuhan masyarakat terhadap hukum, tetapi juga mendorong ketaatan masyarakat terhadap kedudukan nilai-nilai, prinsip-prinsip, dan kaidah-kaidah moral berlandaskan kesadaran diri.

Ketiga, hukum dapat mementuk moralias baru dalam kehidupan masyarakat guna menciptakan ketertiban dalam interaksi sosial. Pembentukan moralitas baru dilakukan melalui penetapan perbuatan-perbuatan yang tidak bersumber kepada kaidah-kaidah moral menjadi perbuatan yang dilarang (tindak pidana) yang disertai ancaman sanksi pidana tertentu. Misalnya, perbuatan dengan sengaja tidak mendaftarkan diri untuk diberikan Nomor Pokok Wajib Pajak (NPWP). Banyak sekali warganegara yang tidak mengetahui bahwa dia punya kewajiban hukum untuk mendaftarkan diri ke kantor pajak guna mendapatkan NPWP. Hanya sebagian kecil warga negara yang menyadari bahwa dia dia punya kewajiab moral (hukum) untuk mendaftarkan diri ke kantor pajak guna mendapatkan NPWP.

Adanya kewajiban moral untuk mendaftarkan diri ke kantor pajak guna mendapatkan NPWP baru muncul setelah undang-undang memerintahkannnya demikian. Tanpa ada perintah undang-undang, maka tidak ada kewajiban moral untuk mendaftarkan diri ke kantor pajak guna mendapatkan NPWP. Menurut kesadaran moral masyarakat, perbuatan dengan sengajaa. tidak mendaftarkan diri untuk diberikan NPWP bukan perbuatan tercela secara moral jika undang-undang tidak menyatakannya demikian. Dalam konteks ini undang-undanglah yang membentuk moralitas baru dalam kehidupan masyarakat.

Kelompok tindak pidana yang dapat membentuk moralitas baru dalam kehidupan masyarakat terutama berkaitan dengan tindak pidana administratif. 
Beberapa contoh tindak pidana yang masuk kategori ini adalah mendirikan bank tanpa ijin, melakukan kegiatan di pasar modal tanpa ijin, persetujuan, dan pendaftaran, mendirikan bangunan tanpa izin, merusak benda cagar budaya, dan tindak pidana di bidang lalu lintas (mengendarai kendaraan tanpa SIM, mengendarai kendaraan bermotor tanpa membawa STNK, parkir di tempat terlarang).

Keempat, hukum melembagakan model pertanggungjawaban moral yang berlandaskan prinsip indeterminisme sebagai dasar pertanggungjawaban hukum. Dalam perspektif moral, hanya perbuatan seseorang yang dilakukan secara bebas, dengan penuh kesadaran, dan tanpa paksaan dari orang lain yang dapat dinilai sebagai perbuatan baik atau buruk. Artinya, perbuatan yang dilakukan seseorang secara bebas dan tanpa paksaan adalah perbuatan yang secara sadar dipilih untuk dilakukan oleh pelakunya, dan karena itu jika perbuatan yang dilakukan adalah perbuatan yang salah, ia dapat dimintai pertanggungjawaban (dipersalahkan) atas perbuatannya itu.

Model pertanggungjawaban moral ini kemudian dijadikan sebagai dasar pertanggungjawaban hukum. Perbuatan melanggar hukum yang dilakukan seseorang secara sadar tanpa paksaan dari orang lain dapat dimintai pertanggungjawaban hukum, dan jika pelaku terbukti bersalah, maka dia dapat dijatuhi hukuman sesuai dengan tingkat kesalahannya. Asasnya, tiada hukuman tanpa kesalahan (geen straf zonder schuld). Kesalahan dalam hukum pidana dapat berupa kesengajaan (dolus) yang esensinya bahwa terdakwa menghendaki (willen) dan mengetahui perbuatan terlarang yang dilakukannya, dan berupa kealpaan (culpa) yang secara konseptual bermakna adanya kelalaian atau ketidakhati-hatian dalam diri seseorang ketika melaksanakan suatu kegiatan yang merugikan orang lain.

\section{Penutup}

Pemikiran mengenai hubungan hukum dan moral bermuara pada dua alur yang bertolak belakang, yaitu pemikiran yang mengakui adanya hubungan hukum dan moral dan pemikiran yang mengingkari hubunan di antara keduanya kaidah itu. Pemikiran yang mengakui adanya hubungan hukum dan moral diwakili oleh mazhab hukum kodrat, sedangkan pemikiran yang mengingkari hubungan itu adalah postivisme.

Dalam konteks ada hubungan antara hukum dengan moral terdapat tiga pola hubungan hukum dan moral, yaitu hukum merupakan bagian dari sistem ajaran 
moral agama atau idiologi, hukum merupakan derivasi dari prinsip-prinsip moral umum, dan persinggungan antara hukum dengan moral.

Adanya hubungan hukum dan moral melahirkan relasi fungsional yang resiprokal antara kedua entitas tersebut dalam pembentukan hukum dan penegakan hukum. Fungsi moralitas terhadap hukum meliputi: sumber etik (nilai) pembentukan hukum positif, sumber kaidah bagi hukum positif, instrumen evaluatif bagi substansi kaedah hukum, dan sumber rujukan justifikasi bagi penyelesaian kasus-kasus hukum yang tidak jelas aturan hukumnya.

Fungsi hukum terhadap moral terdiri dari fungsi mentransformasikan kaidahkaidah moral yang bersifat individual menjadi kaedah hukum yang bersifat sosial dengan dukungan sanksi tertentu, memperkokoh nilai-nilai, prinsip-prinsip, dan kaidah-kaidah moral, membentuk moralitas baru dalam masyarakat, dan sarana untuk menegakkan nilai-nilai, prinsip-prinsip dan kaidah-kaidah moral dalam tatanan kehidupan sosial.

Dalam wacana tidak ada hubungan antara hukum dan moral, terdapat beberapa perbedaan di antara keduanya. Perbedaan itu meliputi perbedaan tujuan, perbedaan substansi aturan, perbedaan asal usul kaidah, perbedaan instrumen penegakannya, perbedaan daya kerjanya dan perbedaan ruang lingkup pengaturan.

\section{Daftar Pustaka}

Aburaera, Sukarno dkk, Filsafat Hukum, Cetakan Pertama, Pustaka Refleksi, Makasar, 2010.

Apeldorn, Van, Pengantar Ilmu Hukum, PT. Pradnya Paramita, Jakarta, 1982.

Basiang, Martin, Law Dictionary, First Edition, Red \& White Publishing, Jakarta.

Bertens, K., Etika, Cetakan Kesebelas, Penerbit Gramedia Pustaka Utama, Jakarta, 2011.

Cruz, Peter de, Perbandingan Sistem Hukum, Penerbit Nusa Media, Jakarta, 2010.

Harris, Sam, The Moral Landscape How Science Can Determine Human values, Transworld Publisher, London, 2010.

Hart, H.L.A., Konsep Hukum The conept of Law, Cetakan Pertama, Penerbit Nusa Media, Bandung, 2009.

Marwan dan Jimmy P, Kamus Hukum, Cetakan Pertama, Reality Publisher, Surabaya, 2009.

Mertokusumo, Sudikno, Mengenal Hukum, Cetakan ke 01, Penerbit Universitas Atmajaya, Yogyakarta, 2010. 
Rahardjo, Satjipto, Penegakan Hukum Progresif, PT. Kompas Gramedia Nusantara, Jakarta, 2010.

Samsudin, M, Budaya Hukum Hakim, Edisi Pertama, Kharisma Putra Utama, Jakarta 2012.

Santoso, M. Agus, Hukum, Moral. E Keadilan, Edisi Perdana, Penerbit Kencana Prenada Media Group, Jakarta, 2012.

Singer, Richard G. dan John Q. La Fond, Criminal Law, $4^{\text {th }}$ ed, Aspen Publisher, New York, 2007. 